\title{
The Four (Animal) Kingdoms: Understanding Empires as Beastly Bodies
}

\author{
Alexandria Frisch
}

\section{$1 \quad$ Daniel and Imperial Bodies}

Put simply, Daniel is a book of empires. ${ }^{1}$ The first half of the book (chapters 1-6) contains six stories that advocate cooperating with foreign kings as Daniel achieves success in an imperial world. ${ }^{2}$ In contrast, the second half of the book (chapters 7-12) details apocalyptic visions, which, in large part, center around the end of empires and their replacement with a divine kingdom. Post-biblical interpreters recognized the imperial focus of the book and similarly used Daniel—whether it be with implicit allusions, explicit references, or entirely rewritten passages - when they wanted to say something, even tangentially, about empires. This deployment of the book of Daniel and its motifs became what I have termed elsewhere as the "Danielic discourse."3

An important part of this discourse was the four kingdoms motif, which was a larger Near Eastern motif depicting a series of empires and which was originally distinct from Daniel. In Daniel, both the narrative and the apocalyptic imagery incorporate a series of empires. The royal court shifts from that of the Babylonians (Daniel 1-5) to Darius the Mede's (Dan 5:31) and then, finally, to Cyrus the Persian's (Dan 6:28). The same three imperial settings repeat in Daniel $7-12 .{ }^{4}$ Beyond the historical setting of the chapters, there are visions in Daniel 2 and 7 that portray a four-part imperial series consisting of Babylonia, Media, Persia, and Greece. Daniel 2 does so with a human-like statue and

1 This is markedly different from most biblical books, which "focus on the behavior and destiny of Israel as the elect nation or on its pious members" (Klaus Koch, "Stages in the Canonization of the Book of Daniel," in The Book of Daniel: Composition and Reception, ed. John J. Collins and Peter W. Flint, VTSup 83 [Leiden: Brill, 2001], 422).

2 See John J. Collins, A Commentary on the Book of Daniel, Hermeneia (Minneapolis: Fortress Press, 1993), 51; and W. Lee Humphreys, "A Life-Style for Diaspora: A Study of the Tales of Esther and Daniel," JBL 92 (1973): 211-23.

3 Alexandria Frisch, The Danielic Discourse on Empire in Second Temple Literature, JSJS 176 (Leiden: Brill, 2017).

4 Daniel 7-8 includes Babylonian kings, Daniel 9 focuses on Darius the Mede, and Daniel 10-12 returns to Cyrus the Persian. There is also the explicit reference to the "prince of Greece" in Dan 10:20. 
Daniel 7 with four ferocious beasts. ${ }^{5}$ In both chapters, the series is inherently anti-imperial as it envisions the end of the final, Greek empire and its replacement with a fifth, divine kingdom. The final redactions of both chapters appear to be reactions to the unstable political situation in Judea prior to the Maccabean Revolt. ${ }^{6}$

As much as Daniel is a book of empires, however, it is also a book of bodies. The four kingdoms are depicted as bodies-human and animal. This is not a coincidence. In the very first chapter, we are introduced to Daniel and his friends with a focus on their bodies - they are "young men without physical defect and handsome" (Dan 1:4). ${ }^{7}$ We learn this even before we are told about their wisdom, even though it is wisdom that enables them to be successful in the foreign court (vv. 17-20). The rest of the story in Daniel 1 continues to concern itself with their bodies. Daniel and his friends eat only vegetables so as not to defile themselves with foreign food and, as a result, "they appeared better and fatter than all the young men" (v. 15). Bodies continue to dominate Daniel - in addition to human bodies forming the shape of statues (Daniel 2 and perhaps Daniel 3), human bodies miraculously survive execution (Daniel 3 and 6), and human bodies can be resurrected from the dead (Dan 12:2). Angelic bodies also appear alongside these human bodies. We read about their clothing

5 In Daniel 2, the statue's head of gold is identified as Nebuchadnezzar, the first kingdom (v. 38). The interpretation of the fourth part, the legs/feet, emphasizes its mixed nature (Dan 2:41-43). Most scholars see this as a reference to the dynastic Ptolemaic/Seleucid intermarriage between Antiochus II and Berenice in 252 BCE or that of Ptolemy Epiphanes and Cleopatra in 193 BCE (John J. Collins, Daniel with an Introduction to Apocalyptic Literature [Grand Rapids: Eerdmans, 1984], 170). The order of Medes and Persians as the second and third kingdoms is supported by the sequence of kings in Daniel 6 and by their pairing in Dan 5:28. Furthermore, in Dan 8:3, the two-horned ram represents the kings of Media and Persia, with the latter appearing afterwards and larger. See Michael J. Gruenthaner, "The Four Empires of Daniel," свQ 8 (1946): 208-9. In order to identify the four beasts in Daniel 7, many scholars have drawn parallels between its animal imagery and animal imagery associated with these empires in extra-biblical sources throughout the ancient Near East. See, for example, Jürg Eggler, Influences and Traditions Underlying the Vision of Daniel 7:1-14: The Research History from the End of the 1gth Century to the Present (Fribourg: Fribourg University Press, 2000), 42-48.

6 The fourth beast of Daniel 7 contains details so specific that scholars have identified the historical setting of its writing as the persecution of the Jews by Antiochus Epiphanes (167 BCE). About the "little horn" in Dan 7:8, Collins writes, "Since the fourth beast has ten horns, a date before the third century is unlikely, and no Greek king before Antiochus Epiphanes is known to have inspired such antipathy among Jews. The identification of the 'little horn' with a 'mouth speaking great things' (7:8) as Epiphanes may be implied already in 1 Macc 1:24 (he 'spoke with great arrogance')" (Daniel, 80).

7 Biblical translations are from the NRSV. 
(Dan 10:5, 12:6), the light streaming from their eyes and face (Dan 10:6), and how they look like men (Dan 3:5, 8:15).

It is the animal bodies, however, that are arguably the most distinctive and varied throughout the entire book as revealed by the following brief overview:

Daniel refuses to eat animals (1:8-17); there is an attempt to feed him to the animals (6:10-24); the king turns into an animal (4:28-37), and animals run amok in the final visions (7-12). The Greek version of Daniel, with its three additional chapters, returns to the animal; Daniel first uses an explosive pitch-laden brisket to slay a monstrous, fire-breathing dragon, before he (alas, again) survives a den of hungry lions $(15: 23-40){ }^{8}$

What is most remarkable about these animals is that they are always connected to imperial power. In fact, they become the actual embodiment of empire. Empires are animals. The same is true in post-biblical interpretations of Daniel as well as in other texts that are contemporaneous with Daniel. In particular, the four kingdoms motif is also reconfigured with animal imagery. This essay will argue that the beastly four kingdoms is itself its own discourse that evinces a specific outlook on empire. ${ }^{9}$

Before delving into the texts that envision the four kingdoms as animals, it behooves us to pause for a moment and make clear that there are other Second Temple texts that do not employ animalistic imagery for the kingdoms. The

8 Jennifer L. Koosed and Robert Paul Seesengood, "Daniel's Animal Apocalypse" in Divinanimality: Animal Theory, Creaturely Theology, ed. Stephen D. Moore (New York: Fordham University Press, 2014), 183.

9 I use "discourse" here to mean speech and the ideas and philosophies propagated by that speech. Since we do not have the verbal speech of Second Temple period Jews, this is a discourse discernible in written texts. For this common-sense definition, see Teun A. van Dijk, "The Study of Discourse," in Discourse as Structure and Process, ed. Teun A. van Dijk (London: Sage, 1997), 1. An early pioneer in the study of discourse, Michael Foucault himself admits that there are various definitions of discourse, one being: "an individualizable group of statements" (Archaeology of Knowledge, trans. A. M. Sheridan Smith [New York: Pantheon, 1972], 8o). As interpreted by Sara Mills, this concept refers to "groups of utterances which seem to be regulated in some way and which seem to have a coherence and a force to them in common. Within this definition, therefore, it would be possible to talk about a discourse of femininity, a discourse of imperialism, and so on" (Discourse [London: Routledge, 1997], 7). 
earliest example is the apocryphal book of Tobit, which uses a narrative to convey the series of empires. On his deathbed, Tobit tells his son to go to Media, because Nineveh (i.e., the Assyrians) will be overthrown. Then he predicts the destruction of the Temple and Jerusalem and the Exile, all of which can only indicate the Babylonian Empire. Finally, the Jews will be freed from their captivity to return to Jerusalem and rebuild the Temple, an allusion to the Persian period (14:4-7). The implicit imperial sequence in Tobit, therefore, is Assyria, Media, Babylonia, and Persia. ${ }^{10}$ Contemporaneous with Daniel, Sib. Or. 4 bears witness to the effects of the Greek conquest and, much like Daniel, adds Greece to the imperial series. The Oracle narrates ten generations of humanity. This ten-generation span is further sub-divided into separate empires. ${ }^{11}$ The Assyrians reign for six generations (4.49-53), the Medes then rule for two generations (4.54-63) followed by the Persians for only one generation $\left(4.65^{-85}\right)$, and, finally, the Macedonians arrive (4.86-87). ${ }^{12}$

Among the Dead Sea Scrolls, two fragments of a work known as the Aramaic "Four Kingdoms" text (4Q552 and 4Q553) depict the four kingdoms as trees. A seer asks each tree its identity. The only preserved answer is from the first tree, which claims to be "Babylon" to which the seer responds, "You are the one who rules over Persia."13 It is possible to infer from the description of another tree, which ruled over "the powers of the sea, and over the harbor," that it is Greece. There is mention of a third tree and something about its "appearance"

10 Given the ex-eventu prophecy, scholars have dated the text to around 200 BCE based on its knowledge of the Greeks, but the lack of any anti-Greek rhetoric suggests it is before the Maccabean Revolt. See Benedikt Otzen, Tobit and Judith (Sheffield: Sheffield Academic, 2002), 57 .

11 We see a similar ten-generation division, but without imperial associations, in the Sib. Or. $1-2$.

12 No specific number of generations is assigned to the Macedonians, because, following the Macedonians, the Oracle describes the Roman rise to power. Since nine out of ten generations have already been covered, there simply are not enough generations to cover the Macedonians and the Romans. The addition of the Romans, thus, necessitated the removal of any explicit identification of the Macedonians's one generation. Therefore, scholars have concluded that Sib. Or. 4.49-101 represents an earlier text comprised of a sequence of Assyrian, Median, Persian, and Greek empires. Since the Macedonians were only allotted one generation, this must mean that the original author did not know the duration of the Greek empires, making the date the early third century все (David Flusser, "The Four Empires in the Fourth Sibyl and in the Book of Daniel," IOS 2 [1972]: 150-51).

13 Translations of the Dead Sea Scrolls are taken from Florentino García Martínez and Eibert J. C. Tigchelaar, eds., The Dead Sea Scrolls Study Edition (Leiden: Brill, 1997). 
(4Q552 $\left.1 \mathrm{i}-\mathrm{ii} 5^{-12}\right) .{ }^{14}$ All that is revealed about the fourth tree is that it is higher than the others with a top reaching the heavens $\left(4 Q_{553}, 61\right) \cdot{ }^{15}$

Similar to these Qumran texts, the pseudepigraphic book of 2 Baruch also imagines the four kingdoms as trees. The first image of empires in 2 Baruch is "a forest with trees that was planted on the plain and surrounded by high mountains and rugged rocks" (36:2). The interpretation of the dream makes it clear that these trees are four kingdoms. ${ }^{16}$ Given that 2 Baruch was written after the destruction of the Temple, the final kingdom, a cedar, is Rome (36:7). Thus, we can see that in Jewish circles the four kingdoms motif was inserted into diverse genres - a deathbed prophecy, an oracular declaration, or dreamvisions-and reworked using different images-historical events, generations of humanity or elements from the world of flora. Given that depicting empires as animals is a choice on the author's part, then why depict the Four Kingdoms as fauna?

To answer this question, I would like to use a hermeneutical lens provided by the relatively new field of animal studies. Focusing on the animal is part of a recent turn that follows on the theoretical heels of postcolonial studies, queer theory and feminist criticism. Much like these earlier fields that attempted to resurrect the lost perspectives of subalterns, women, or those who did not fit into neat binaries, animal studies "advocated for equal consideration for

14 Peter W. Flint ("The Daniel Tradition at Qumran," in The Book of Daniel: Composition and Reception, ed. John J. Collins and Peter W. Flint, VTSup 83 [Leiden: Brill, 20o1], 362) understands the reference to the appearance of the third tree to mean that it is different, which, in turn, makes it comparable to the fourth beast of Daniel 7 , which "was different from all the former beasts" (Dan 7:23).

15 Because the text is so fragmentary, a number of possibilities exist for the four trees' identities, such as (1) Babylonia-Persia, Greece, Rome, and an eschatological Kingdom of Israel; or (2) Babylonia-Persia, Greece, Syria. See Flint, "The Daniel Tradition," 362-63; and Loren T. Stuckenbruck, "The Formation and Re-Formation of Daniel in the Dead Sea Scrolls," in Scripture and the Scrolls, vol. 2 of The Bible and the Dead Sea Scrolls, ed. James H. Charlesworth (Waco: Baylor University Press, 2006), 101-3o. Regardless, the inclusion of Rome in the list seems likely as it accords well with the proposed dating of both manuscripts to the early first century CE (Flint, "The Daniel Tradition," 332). See also the contribution by Andrew Perrin in this volume.

16 The interpretation in 2 Bar. 39 is explicit about four kingdoms, but the dream is not. Matthias Henze highlights this difference (Jewish Apocalypticism in Late First Century Israel: Reading Second Baruch in Context, TSAJ 142 [Tübingen: Mohr Siebeck, 2011], 264). Although he raises the possibility that the dream and interpretation come from different sources, I think the "disappearance" of the other kingdoms is better explained by a telescoping effect, which focuses on the contemporaneous empire that the writer is living under. The same is true of the interpretations of the fourth kingdoms in Dan 2:40-43 and Dan 7:19-26. 
animals."17 Some scholars went so far as to accuse humanists of a "speciesism" that assumed humans were the only ones who inhabited the ethical world. ${ }^{18}$ Thus, much of animal studies originated among philosophers. For example, in a seminal piece entitled The Animal That Therefore I Am, Derrida even criticizes our use of the term "the Animal," placing it in quotations and writing that it is a "catch-all concept" that has been used to "designate every living thing that is held not to be human" and one that ignores the "heterogeneous multiplicity of other living things." 19

Animal studies, however, is only beginning to experience a turn within biblical and Jewish studies. In Reading the Bible with Animal Studies, Ken Stone argues that it is the "multispecies context" of the Hebrew Bible that shapes biblical theology and, thus, the development of Judaism and Christianity. ${ }^{20}$ The reason is as follows:

Claude Lévi-Strauss famously observed that animals are not only "good to eat" but also "good to think" ... When the writers of biblical literature "thought" with animals, however, they were not only thinking about animals. They were, in addition, using their observations about and relations with animals to understand themselves, their relations with one another (including the relations of power and subordination that structured their societies), their relations with other peoples and nations, their relations with God. ${ }^{21}$

17 Beth A. Berkowitz, Animals and Animality in the Babylonian Talmud (Cambridge: Cambridge University Press, 2018), 10. In other words, there has been a critique of "the apparatus that melds all life forms other than the human into the single essence known as 'the animal,' and they see the human/animal binary as similar and related to other reductive binaries: white/black, male/female, straight/gay, able-bodied/disabled, culture/ nature, and so forth" (Berkowitz, Animals and Animality, 18).

18 See, for example, Kari Weil, who writes, "Influenced by postmodern theory and by feminist and postcolonial critiques of the ways Western, educated Man has acted as the norm for what counts as human, recent discussions in animal studies have questioned to what extent our understanding of rights and protection are adequate for humans" (Thinking Animals: Why Animal Studies Now? [New York: Columbia University Press, 2012]: 4-5). For an overview of the field, see also Cary Wolfe, "Human, All Too Human: 'Animal Studies' and the Humanities" PMLA 124 (2009): 564-574.

19 Jacques Derrida, The Animal That Therefore I Am, trans. Marie-Louise Mallet (New York: Fordham University Press, 2008), here 34, 31, 48.

20 Ken Stone, Reading the Hebrew Bible with Animal Studies (Stanford: Stanford University Press, 2018), 4. For a history of Western philosophers who cite the biblical text as their foundation for thinking about animals, see Hannah M. Strømmen, "Beastly Questions and Biblical Blame," in The Bible and Posthumanism, ed. Jennifer L. Koosed (Atlanta: SBL Press, 2014), 13-28.

Stone, Reading, 5 . 
Similarly, in Animals and Animality in the Babylonian Talmud, Beth Berkowitz explores the rabbinic conceptualization of animals and animality. ${ }^{22}$ She argues that:

the Babylonian Talmud created a discourse about animals that imagines them as agents and subjects in new ways, as "persons" with the capacity to exercise intention and plan for the future, to experience pleasure and be held accountable for sin, to undergo suffering ... and to break free of the property category into which they are usually placed. ${ }^{23}$

Together, these two works, among others, serve as the basis for my thinking about the animality that pervades those texts that use the four kingdoms motif. Given that the four kingdoms motif is a discourse used to deny the inevitable and eternal nature of imperial power, then, I would argue that the animalistic version of the four kingdoms is itself a discourse within a discourse.

In Daniel 7, Daniel recounts his vision of four beasts coming up out of the sea (v. 3) and an interpreting angel reveals that they represent four kings (v. 17). At first glance, they serve an obvious function - to terrify Daniel (v. 15). And it is no wonder why. Each of the beasts shares features or behaviors with carnivores. The first is like a lion and has eagle wings (v. 4). The second resembles a

Within the field of rabbinic studies, see also the recent work of Mira Beth Wasserman, Jews, Gentiles, and Other Animals: The Talmud After the Humanities (Philadelphia: University of Pennsylvania Press, 2017). Wasserman explores the tractate of Avoda Zara using animal studies along with gender studies, critical race studies, disability studies and new materialisms, which all contribute to "posthumanism" and the realization that human life is embedded "within complex cultural, ecological, and technological systems" (Jews, Gentiles, and Other Animals, 4). In particular, Wasserman understands the rabbis as telling stories that "invite readers to survey the wide compass of experience that Jews and non-Jews share in common, as human beings, as animals, and as material bodies" (Jews, Gentiles, and Other Animals, 5). Thus, she, in part, uses animal studies to answer the question, "What does it mean to be human?" Similarly, Jennifer L. Koosed poses the same question vis-à-vis the Bible: "the Bible also contains multiple moments of disruption, boundary crossing, and category confusion: animals speak, God becomes man, spirits haunt the living and monsters confound at the end. All of these stories explore the boundaries of the human in ways that destabilized the very category of the human" " $\mathrm{Hu}$ manity at Its Limits," in The Bible and Posthumanism, ed. Jennifer L. Koosed [Atlanta: SBL Press, 2014], 3).

Berkowitz, Animals, 19. 
bear, but one in the midst of eating as it has ribs hanging out of its mouth and it is commanded to devour (v. 5). The third is like a leopard (v. 6). Although the fourth creature lacks a specific animal comparison, it has horns and "great iron teeth" (v. 7). Like the second beast, the fact that it kills is emphasized-it devours, breaks things into pieces, and stomps whatever is left (v. 7).

In addition to being carnivores, these animals are wild. The expectation is that they will kill, maim, damage, and eat. ${ }^{24}$ In fact, the lion, the bear and the leopard appear in a prophecy by Hosea in which God declares how Israel, depicted as sheep, will be punished:

So I will become like a lion to them,

like a leopard I will lurk beside the way.

I will fall upon them like a bear robbed of her cubs, and will tear open the covering of their heart;

there I will devour them like a lion, as a wild animal would mangle them HOSEA 13:7-8

These animals are a metaphor for divine punishment, which, "shows that familiarity with animals supplied the Bible's writers, not only with positive symbols of care and sustenance, but also frightening symbols of danger. It comes from a world in which the risk of losing domesticated animals to wild ones was real." 25

Yet, Daniel 7's animals are more than just dangerous - they are outside of divine creation. While the beasts are stirred up by four winds of heaven (v. 2), they are not divine forces, but harken back to the primordial world. ${ }^{26}$ The sea is not the Mediterranean, but the watery chaos that existed before creation. ${ }^{27}$

24 Three of these animals - the lion, the bear and the leopard-appear in rabbinic literature as species for whom aggressive behavior is considered normal and, therefore, anyone who owns them is automatically liable for damages they cause (Berkowitz, Animals, 129).

25 Stone, Reading, 117.

26 The verb used in Dan 7:2- גוחי "to stir up" -is similarly used in Job 38:8 to describe the moment of creation that the sea ushered forth (Collins, Daniel, 294). In Gen 1:2, a divine wind hovers over the deep waters at the very beginning of creation, but peacefully; the winds do not touch the sea. See Jacques B. Doukhan, "Allusions à la création dans le livre de Daniel," in The Book of Daniel in The Light of New Findings, ed. A. S. van der Woude (Leuven: Leuven University Press, 1993), 289.

27 The sea is related to cosmogonic battles throughout the biblical text (e.g., Ps 29; 68; 74; 89; 104; Isa 27:1; 51:9-11; Job 3; 7; 26; 40-41). See André Lacocque, "Allusions to Creation in Daniel 7," in The Book of Daniel: Composition and Reception, ed. John J. Collins and Peter W. Flint, VTSup 83 (Leiden: Brill, 2001), 127-28. 
The beasts are like those other primordial creatures that inhabit the sea. In Isaiah, we read of two dragon sea creatures: Leviathan (Isa 27:1) and Rahab (Isa 51:9). ${ }^{28}$ The sea itself also must be defeated by God. In Canaanite mythology that battle is personified as Yamm, the sea god, is vanquished by the Ugaritic head god Baal. In the biblical text, the sea comes to represent not an opposing deity, but enemy nations. ${ }^{29}$ Thus, having beasts from the sea represent enemy empires fits into these already established biblical motifs.

The absence of God in Daniel 7 further suggests that the beasts' creation positions them against God. Moreover, the beasts are distorted versions of themselves, making them not only "predators but monsters, composite creatures mutated beyond the natural order." ${ }^{30}$ For example, the third beast has four wings and four heads (v. 6). The beasts of this vision are dangerous not only because of their innate predatory behavior, but because they are embodied chaos, defying the categories of human and animal that make up the ordered world. ${ }^{31}$ They must be destroyed and, indeed, later in the vision they are (vv. 11-12).

While other scholars have previously argued that the beasts are meant to symbolize the turmoil that is empire, ${ }^{32}$ a focus on animal theory helps us to see how the animals relate to the humans in Daniel. As Walter Benjamin writes: "In an aversion to animals the predominant feeling is fear of being recognized by them through contact. The horror that stirs deep in man is an obscure awareness that in him something lives so akin to the animal that it might be recognized."33 In other words, animals remind us that we too are merely

28 Leviathan similarly appears in Job 3:8; 41:1; Ps 74:14; 104:26. Rahab is described as a dragon in Job 9:13; 26:12; Ps 89:10.

29 Collins sees Daniel 7 , in particular, as "a reasonable extension of the traditional symbolism, in view of the identification of the sea monster (e.g., Rahab) with the political enemies of Israel in the Bible" (Daniel, 289 n. 96). See, for example, Isa 17:12-13. For a review of the parallels with Canaanite mythology and, in particular the Baal cycle, see Collins, Daniel, 286-94; and Lacocque, "Allusions to Creation," 118. The Babylonian Enuma Elish also features the god Marduk defeating Tiamat, the goddess of watery chaos.

30 Anathea E. Portier-Young, Apocalypse Against Empire: Theologies of Resistance in Early Judaism (Grand Rapids: Eerdmans, 2011), 171.

31 Portier-Young, Apocalypse Against Empire, 171.

32 In addition to Portier-Young, see also Rebecca Raphael, "Monsters and the Crippled Cosmos: Construction of the Other in Fourth Ezra," in The "Other" in Second Temple Judaism: Essays in Honor of John J. Collins, ed. Daniel C. Harlow, et al. (Grand Rapids: Eerdmans, 2011), 287-9o; and David Bryan, Cosmos, Chaos, and the Kosher Mentality, JSPSup 12 (Sheffield: Sheffield Academic Press, 1995), 239.

33 Walter Benjamin, Reflections, Essays, Aphorisms, Autobiographical Writings, trans. Edmund Jephcott (New York: Harcourt Brace Jovariovich, 1986), 66-67. 
animals. This realization is made all the more vivid for Daniel who sees that the beasts display human characteristics.

The first beast is "lifted up from the ground and made to stand on two feet like a human being; and a human mind was given to it" (v. 4). With the second, like the first, there is an emphasis on its standing; it is raised up on one side and told to "arise!" (v. 5). The fourth has one horn with "eyes like human eyes" and "a mouth speaking arrogantly" (vv. 8, 20). It is no wonder that Daniel says that "my spirit was troubled within me and the visions of my head terrified me" (v. 15) and, even once the interpretation is given, he still relates, "my thoughts greatly terrified me, and my face turned pale; but I kept the matter in my mind" (v. 28). If we consider this in terms of the four kingdoms motif, then the forecasted history of empires is one that is meant to instill horror in the viewer. ${ }^{34}$ Daniel can barely react. This is typical of horror, because "unlike fear, which presents a viable strategy (run!), horror denies flight as an option. And it seems to deny fight as an option too." ${ }^{35}$ This mirrors the passivity of the book's reaction to empire as a whole, which does not advocate rebellion. ${ }^{36}$ Instead, all Daniel can do is wait for the resolution of these imperial eras with the arrival of the envisioned fifth, divine kingdom.

The human-animal boundary, however, remains intact in this vision. In contrast to the semi-human beasts, explicitly human figures will usher in the end of empire. The Ancient of Days, representing God, is depicted as humanlike with white clothing and hair. He sits on a throne to decree judgment upon the beasts (vv. 9-10, 22) and gives final authority to another humanlike figure- the son of man (vv. 13-14). The identity of this figure is much debated. ${ }^{37}$ Although some scholars have argued that the son of man should be understood collectively as Israel, given that the Ancient of Days as God is more "mythic-realistic" than symbolic, it makes sense to similarly understand the son of man, who comes in with the clouds of heaven, as a divine being. ${ }^{38}$

Thus, in Daniel 7 there are multiple points represented along an animalhuman-divine spectrum. Daniel, clearly human, stands on one end. Alongside

34 William Ian Miller writes that "vision is the sense through which much of horror is accessed" because "vision activates our sympathetic imaginative powers" (The Anatomy of Disgust [Cambridge, MA: Harvard University Press, 1997], 81).

35 Miller, Anatomy of Disgust, 26.

36 Chapters 1-6 advocate assimilation or martyrdom whereas chapter 12 offers up divine justice after death as a solution to the evil on earth.

37 See the overview of this debate in Carol A. Newsom with Brennan W. Breed, Daniel: A Commentary, отL (Louisville: Westminster John Knox, 2014), 234-36.

38 John J. Collins, The Apocalyptic Vision of the Book of Daniel (Missoula: Scholars Press for Harvard Semitic Museum, 1977), 6. 
of him is all that is divine (i.e., the Ancient of Days and Son of Man), which, while not ontologically human, are associated with Daniel via their human imagery. This parallel ultimately enhances the position of Daniel and all of Israel. On the other side are the empires. Their beastly natures dominate, revealing that they are more animalistic than even known animals. While their occasional human characteristics terrify Daniel, they also serve to underscore that although, in actuality, empires are comprised of human rulers and subjects, they do not merit a human depiction.

Contemporaneous Texts in the Hellenistic Period

Given the turbulence experienced under the Ptolemies and Seleucids and, most particularly, during the reign of Antiochus IV, ${ }^{39}$ it is no coincidence, then, that a similar combination of animal imagery and the four kingdoms motif appears in two other texts that are contemporaneous with Danielthe Testament of Naphtali and the Animal Apocalypse. In the Testament of Naphtali, dated to the second century $\mathrm{BCE}^{40}{ }^{40}$ Naphtali has a dream in which sacred writing predicts, "Assyrians, Medes, Persians, Elamites, Gelachians, Chaldeans, Syrians shall obtain a share in the twelve staffs of Israel through

39 During the years of conflict between the Ptolemies and Seleucids, different factions had developed in Jerusalem that supported one side or the other. The Gerousia, the council of elders, the high priest Simon the Just, and the Tobiads all backed the Seleucids whereas the former high priest Onias III and the Oniad family supported the Ptolemies. It was the disagreement between these two factions that led to the disruption of the hereditary succession of the high priesthood, making it into a position that was given to the highest bidder by Antiochus IV. This change, combined with an increasing movement towards Hellenization, led to popular discontent, restrictions on religious practice, and, ultimately, the Maccabean revolt. The scholarly consensus follows Tcherikover's theory, based on 2 Maccabees, that Antiochus instituted restrictive religious measures as a response to rising tensions, not that the revolt followed the persecutions (Victor Tcherikover, Hellenistic Civilization and the Jews [Philadelphia: Jewish Publication Society], 191). In sum, the reign of Antiochus IV was filled with extreme conflict.

40 This date is based on the text's reference to Syria (i.e., Greece), not Rome, as the last empire. A second century вСЕ date is also suggested by the fact that the Testament shares a genealogy of Bilhah (T. Naph 1:6-12) with a scroll from Qumran (4Q215) as well as the concept of a dual messiahship with Qumran theology. The Testament of Naphtali is extant both in Greek and in late Hebrew. However, there is no clear evidence that a full Hebrew testament existed prior to the Greek as it might merely reflect a tradition used by the Greek author. See Robert A. Kugler, The Testaments of the Twelve Patriarchs (Sheffield: Sheffield Academic Press, 2001), 28-29; and H. C. Kee, "Testaments of the Twelve Patriarchs," отP, ed. James H. Charlesworth (Garden City, NY: Doubleday, 1983), 1:775-8o. 
captivity" (T. Naph. 5:8). ${ }^{41}$ While the list consists of more than four empires, the beginning of this list echoes the Assyrian-Median-Persian scheme of Tobit and Sib. Or. 4. The Syrians at the end of the list parallel Daniel's addition of the Greeks to the four kingdom series. ${ }^{42}$ The Testament further associates this imperial sequence with a hybrid animal. Before the sacred writing, there appears a vision of "a bull on the earth with two great horns and an eagle's wings on his back" (T. Naph. 5:6). Given the imperial concerns of the dream, it is plausible that the bull with the horns represents the Seleucids and the Ptolemies ${ }^{43}$ and the eagle represents the rising power of the Romans. ${ }^{44}$ As in Daniel 7 , the seer cannot control this beast, saying, "we wished to seize him, but could not" (T. Naph. 5:6). Instead, like the son of man, it takes an esteemed human figure to conquer the beast- "Joseph came, and seized him, and ascended up with him on high" (T. Naph. 5:7).

An even more extensive version of the animalistic four kingdoms motif appears in the Animal Apocalypse, 1 Enoch 85-90, which dates to 164-16о вСE at the end of the Maccabean Revolt. ${ }^{45}$ This apocalypse details one of Enoch's dreams as he retells it to his son Methuselah. Encompassing the entire course of history, the dream begins with an abbreviated recounting of the Watchers's rebellion (1 En. 86-88) from 1 Enoch 7. In particular, the myth of Shemihazah is retold with the Watchers as stars and the humans as cattle grazing. The fallen stars turn into bulls, so that they are able to impregnate the cows. As in 1 Enoch 7 , the mating results in distinct progeny. Instead of giants, however, the cows give birth to elephants, camels, and asses. Although these animals in and of themselves are not unnatural, the fact that they are a different species from the cattle who give birth to them and different from one another evokes a sense

\footnotetext{
41 This list does not exist in the later Hebrew Testament of Naphtali.

42 The placement of the Chaldeans, which may represent the Babylonians, is notably odd, but seems to reflect the undeniable knowledge that the Babylonians also oppressed the Jewish people (Kee, "Testaments," 812).

43 While there is no mention of a bull in Daniel, the horns on the fourth beast in Dan 7:7-8 (as well as the he-goat with horns in Dan 8:8-9, 21-22) also represent Greek rulers.

44 Kee, "Testaments," 813. The eagle as symbolic of Roman rule is well attested in both Roman and Jewish literature as will be shown below in the discussion of 4 Ezra. There is also the possibility that the eagle could instead represent the Greeks as we shall see below in the discussion of the Animal Apocalypse.

45 The consensus for this date stems from: (1) references to the Maccabean war (see, for example, the "ram with a large horn" in 1 En. 9o:9, which is thought to represent Judah Maccabee); (2) the evidence of Aramaic fragments found at Qumran (based on paleography, $4 \mathrm{QEn}{ }^{\mathrm{f}}$ is the oldest, dating to the third quarter of the second century BCE); and (3) the Apocalypse's incorporation of the earlier, third century всЕ Book of Watchers. See Patrick Tiller, A Commentary on the Animal Apocalypse of 1 Enoch, EJL 4 (Atlanta: Scholars Press, 1993), 61-82.
} 
of disorder similar to what we saw with the hybrid animals in Daniel 7 and the Testament of Naphtali. ${ }^{46}$ The behavior of these offspring is also disturbing. ${ }^{47}$ Although they are naturally herbivores, they begin to act like carnivores as they "bite with their teeth and devour and gore with their horns" all of the cattle (1 En. 86:5).$^{48}$ The offspring then turn on one another (1 En. 87:1). ${ }^{49}$ As a result, the response is the same as in Daniel 7-horror. The "sons of the earth began to tremble" (1 En. 86:6) ${ }^{50}$ and even the earth itself "began to cry out" (1 En. 87:1).

The elephants, camels, and asses (presumably those that have not yet been killed) are punished with the flood (1 En. 89:6). However, unnatural births continue afterwards, suggesting that something of the original three animals remains. ${ }^{51}$ Three bulls, the sons of Noah, begin "to beget wild beasts and birds, so that there arose from them every kind of species: lions, leopards, wolves, dogs, hyenas, wild boars, foxes, conies, pigs, falcons, vultures, kites, eagles, and ravens" (1 En. 89:10). These animals represent the foreign nations of Genesis 10. Like the elephants, camels, and asses, these nations, who are all either predators or scavengers, behave in a vicious manner, biting one another (1 En. 89:11). ${ }^{52}$ In turn, some of these nations are empires. For example,

46 For a list of similarities between the Animal Apocalypse and Daniel 7, see James R. Davila, "The Animal Apocalypse and Daniel," in Enoch and Qumran Origins: New Light on a Forgotten Connection, ed. Gabriele Boccaccini (Grand Rapids: Eerdmans, 2005), 35-38.

47 Bryan refers to this as "concept collapse" in which there is a "deliberate breaking of the bounds of the imagery by the seer in order to stress the extreme character of the chaos which had invaded the created order" (Cosmos, Chaos, 96).

48 It is unclear who the subject of the action is in this verse. Here I follow George Nickelsburg in assuming that the "devouring" in 1 En. 86:5b and 6a parallel each other, making the offspring the actors (1 Enoch 1: A Commentary on the Book of 1 Enoch, Chapters 1-36, 81-108 [Minneapolis: Fortress Press, 2001], 374).

49 Nickelsburg has "bulls" (1 Enoch 1, 364), but, like Tiller, describes these as human beings $(1$ Enoch 1, 374) not the stars that have turned into bulls. Matthew Goff ("Monstrous Appetites: Giants, Cannibalism, and Insatiable Eating in Enochic Literature," JAJ 1 [2010]: 19-42) understands this verse to mean that the giants are devouring the Watchers.

50 Nickelsburg points out that here the author has departed from his animal symbolism in a way that "underscores the universal human terror that is the reality behind this part of the allegory" (1 Enoch 1, 374).

51 Tiller sees the same parallel: "that unnatural birth is a negative symbol is verified by the fact that it is paralleled by the unnatural birth of elephants, camels, and asses from stars and cows" (Commentary, 271).

$5^{2}$ Nickelsburg, likewise, notices a parallel: "soon the beasts will turn on the Israelites as the giants had turned on humanity" (1 Enoch 1, 377). Bryan (Cosmos, Chaos, 168-85) and Tiller (Commentary, 28-29) emphasize the distinction of clean (i.e., the sheep) versus unclean animals (i.e., the beasts). While this is true, it is because they are predators that they are unclean in the first place, so it is their natural behavior that is the primary distinguishing characteristic. 
the lions and leopards that "devoured and swallowed up most of those sheep" and then "burnt down that tower and demolished that house" (1 En. 89:66) are an allusion to the Babylonians and their destruction of the Temple. The return from exile under Persia follows, but soon eagles began to "devour those sheep and peck out their eyes and devour their flesh" (1 En. 90:2). These are the Greeks under Alexander the Great, who then divide into the Ptolemies, as kites (1 En. 90:2, 4, 11, 13, 16), and the Seleucids, as ravens (1 En. 90:2, 8, 9, 11, 12). The association of the animals with empires is further underscored by the division of animals into four imperial periods, which consist of seventy consecutive "hours" (1 En. 89:72) and are allotted to the care of seventy shepherds. After we read about the destruction of the Temple, the Babylonian period concludes with the statement that "the shepherds were pasturing for twelve hours" (1 En. 89:72). Twenty-three shepherds are allotted to the Persian period (1 En. 89:72). Twenty-three shepherds also correspond to the Ptolemies and, finally, twelve to the Seleucids..$^{53}$ This four-part division uses the four kingdoms motif and populates it once more with wild animals.

Thus, we can trace a distinct line from the giants to the first nations to the four empires via their animal symbols, all of which are violent and unnaturally begotten. For the author of the Animal Apocalypse, the implicit message appears to be that the voraciousness of the empires in his present day has its origins in the voraciousness of the giants before the flood. The connection between the antediluvian and postdiluvian animals is confirmed by the explicit parallelism of their demise. The antediluvian animals are given a sword to destroy each other (1 En. 88:2), and then they "sank to the bottom" during the flood (1 En. 89:6). Similarly, the postdiluvian, imperial animals are also destroyed by sinking into the earth (1 En. 9o:18) and by a sword (1 En. 90:19). This lineage underscores the degree to which the empires are ungodly. They stem from the same divine disobedience enacted by the Watchers.

As in Daniel 7 and the Testament of Naphtali, the emphasis on zoomorphic symbols also highlights by contrast the human figures in the text. Since all humans are symbolized as animals in the apocalypse, any humans, in turn, represent angelic beings. ${ }^{54}$ The seventy shepherds mentioned above are given power

53 See 1 En. 89:65-72a; 89:72b-90:1; 90:2-5, 6-19. This division is that of Nickelsburg, 1 Enoch 1 , $387-88$. While others agree on the division into four periods, they do disagree slightly on the division of the verses. See, for example, Tiller, Commentary, 55; and Bryan, Cosmos, Chaos, 53 .

54 Bennie H. Reynolds II reads many of the symbols in the Animal Apocalypse as sharing "the same representation techniques" as in Daniel (Between Symbolism and Realism: The Use of Symbolic and Non-Symbolic Language in Ancient Jewish Apocalypses 333-63 B.C.E., JAJSup 8 [Göttingen: Vandenhoeck \& Ruprecht, 2011], 167). For example, humans (and 
from God to either to protect or to destroy the sheep, or Israel (1 En. 89:59-61). The shepherds do this via the beasts. For example, the shepherds "abandoned those sheep into the hands of the lions. And the lions and leopards devoured and swallowed up most of those sheep" (1 En. 89:65-66). The shepherds are overzealous in their destruction (1 En. 89:61-64), so seven white men, another group of angels, throw them into a fiery abyss (1 En. 90:24-25). It is clear that imperial power is merely an illusion. The interplay of empires is only a reflection of the true power, divine power, as embodied by the humans in the text. ${ }^{55}$

After considering these three texts from the Hellenistic period-Daniel, Testament of Naphtali and Animal Apocalypse - a few aspects of the animalistic four kingdom motif become apparent. Firstly, the animals are all dangerous. Either they are predators, like the lion or the leopard, or they behave wildly, like the bull. The obvious implication is that empires are powerful and apt to destroy those whom they subjugate. Secondly, all of the animals are unnatural. They are either hybrids or have unnatural origins, making them as much monsters as animals. The implication here is that empires are ungodly. They are not part of what should be a divine, ordered world. Moreover, they instill horror. They are unlike any power that has been experienced and so there is no recourse but to wait out the time of empires. Finally, by focusing on the animals our attention is by default honed in on that which is human in the text. The "humans," even when they represent the angelic, serve to end the four kingdoms. Thus, that which has the power to end empires is antithetical to empires. A binary between animal/human serves to underscore a similar binary between imperial kingdom/divine kingdom.

A change to the neat binary between animal/human, however, occurs in the Roman period. In the aftermath of the destruction of the Temple and under

stars) symbolize angels in Daniel 7-8 as well, which points to "some deep structures within the language of Ancient Jewish apocalypses" (Reynolds, Between Symbolism and Realism, 171). He concludes that this shared symbolic language "must have been intended for large audiences" (Reynolds, Between Symbolism and Realism, 223). My survey of the frequent use of the animalistic four kingdoms motif lends support to Reynolds's argument. Not only were diverse Jewish writers acquainted with this symbolic motif, their use of it suggests that they anticipated widespread familiarity with it among their audiences as well.

55 One could argue that the people of Israel are similarly empowered by their association with the divine as they are at times depicted as animal figures who turn into humans. For example, Moses first appears as a sheep, but becomes an angel after ascending Mount Sinai (see 1 En. 89:16-36). 
the full weight of Roman imperial rule, two texts-Fourth Ezra and the book of Revelation - continue to use animal imagery to allude to empires. However, they alter the four kingdoms to focus in on one kingdom and they abandon the animal/human binary entirely.

The Fourth Book of Ezra (4 Ezra) is a reaction to the destruction of the Second Temple, dating to post-70 CE. ${ }^{56}$ Thus, even though the text sounds as if it comes from Ezra of the First Temple era, it actually responds to the imperial rule of the Romans. ${ }^{57}$ In 4 Ezra 11-12, Ezra dreams of an eagle with twelve wings and three heads that comes up from the sea (4 Ezra 11:1), a clear echo of the beginning of Daniel 7. The eagle is specifically identified as the fourth beast (4 Ezra 11:40). The author of 4 Ezra must have realized that the fourth beast of Daniel, the Greek Empire, was neither destroyed nor replaced by the anticipated divine kingdom. Instead, the Roman Empire superseded it. As a result, Daniel's fourth beast was no longer relevant, but needed to be reimagined as the most powerful beast yet-an eagle. ${ }^{58}$ This eagle, in turn, "conquered all the beasts that have gone before" (4 Ezra 11:40). While it is unclear whether the fourth beast was responsible for defeating the other beasts in Daniel 7 , there is no such confusion in 4 Ezra.

Less explicitly, however, the eagle's characteristics incorporate those of the first three beasts in such a way that it appears to have subsumed (or consumed?) them into itself. The eagle resembles the first beast who had the wings of an eagle (Dan 7:4) and the third beast who had wings like a bird (Dan 7:6). The third beast also has multiple heads like the eagle (although four instead of three). Other attributes are echoed, but inverted. While the cosmic winds create the beasts in Daniel 7 , the eagle controls the elements, spreading "his wings over all the earth and all the winds of heaven blew upon him and the clouds were gathered about him" (4 Ezra 11:2). Daniel's third beast received dominion (Dan 7:6), but the eagle takes it for itself: "The eagle flew with his wings to reign over the earth and over those who dwell in it. And I saw how all things under heaven were subjected to him and no one spoke against him" (4 Ezra 11:5-6).

$5^{6} \quad$ The consensus, which is partly based on Clement of Alexandria's citation of 4 Ezra in his second century CE work, Stromateis, is that the book was composed during Domitian's reign (81-96 CE). Additionally, scholars have attempted to identify the emperors symbolized in the eagle's body parts (chapters 11-12). For more on the dating, see Michael E. Stone, A Commentary on the Book of Fourth Ezra (Minneapolis: Fortress Press, 199o), 9-10.

57 I have previously discussed the eagle of 4 Ezra in Alexandria Frisch, "Matthew 24:28: 'Wherever the Body is, There the Eagles Will Be Gathered Together' and the Death of the Roman Empire," in The Gospels in First Century Judaea, ed. R. Steven Notley and Jeffrey P. Garcia, JCPS 29 (Leiden: Brill, 2015), 79-81.

$5^{8}$ Laura Bizzarro, "The 'Meaning of History' in the Fifth Vision of 4 Ezra," in Interpreting 4 Ezra and 2 Baruch: International Studies, ed. Gabriele Boccaccini and Jason M. Zurawski, LSTS 87 (New York: T\&T Clark, 2014), 33 . 
In Daniel, the first beast "was lifted up from the earth and made to stand on two feet like a human being" (Dan 7:4), and the second beast "was raised up on one side" (Dan 7:5). The eagle, in contrast, stands by itself as it "rose upon his talons" (4 Ezra 11:7). Instead of receiving endorsement from an external voice (Dan 7:5), the eagle uses its own voice: "[The eagle] uttered a cry to his wings, saying, 'Do not all watch at the same time; let each sleep in his own place, and watch in his turn, but let the heads be reserved for the last"' (4 Ezra 11:7-11). The inversion of these beastly characteristics makes the eagle appear more powerful than any of Daniel's three beasts, who seem passive by comparison.

In addition to amplifying the power of the eagle, the author of 4 Ezra has done something that we have not seen thus far with the four kingdoms motifhe has collapsed it into one kingdom. That one, in turn, is all the stronger for subsuming the identities of the previous three; it commands the winds, it seizes dominion, it rises up, it speaks. The fourth kingdom - the eagle — is not just the most powerful empire, it is ultimately the only one.

Yet, the author does not stop there. As we have seen, the Jewish renditions of the four kingdoms motif have been used to convey an anti-imperial message and the author of 4 Ezra is no different. Although the eagle appears to be far more powerful than any of Daniel's beasts, a further comparison with them reveals that it is doomed. In Daniel, a voice speaks to the second beast encouraging it to be oppressive- "Arise, devour much meat!" (Dan 7:5). In contrast, when a voice speaks to the eagle, it forecasts its eventual demise: "Hear me, you who have ruled the earth all this time. I announce this to you before you disappear. After you no one shall rule as long as you, or even half as long" (4 Ezra 11:16-17). The second beast in Daniel has three ribs in its mouth (v. 5) and the fourth beast has great iron teeth that it uses to eat (Dan 7:7) ${ }^{59}$ The eagle, in contrast, devours itself as "the head turned with those that were with it and devoured the two little wings which were planning to reign" (Dan 11:31) and "the head on the right side devoured the one on the left" (Dan 11:35). ${ }^{60}$ The total dominion of the eagle, therefore, only serves to forecast its total destruction. Indeed, we read that its whole body is burnt up (4 Ezra 12:3). Herein lies the motivation behind collapsing the four kingdoms into one: with the eagle's destruction, the author of 4 Ezra is able to affirm the end of the entire phenomenon of empire, not just one, individual empire.

59 Collins, Daniel, 298, compares the ribs in the bear's mouth with Amos 3:12 to show that the bear is eating its prey.

6o As Raphael put it, "The passive lends a touch of inevitability, as if such evil monsters simply self-destruct, unable to sustain their own chaos" ("Monsters," 290). 
The specific identification of the kingdom as an eagle gives added force to this altered four kingdom motif. The Romans themselves often equated their rule with the eagle. For example, in 106 вСЕ, Consul Marius made the eagle the sole symbol of the Roman army's legions as part of his military reform. ${ }^{61}$ Josephus informs us that this symbol was known to those in Judea: "Next the ensigns surrounding the eagle, which in the Roman army precedes every legion, because it is the king and the bravest of all birds; it is regarded by them as the symbol of empire, and whoever may be their adversaries, an omen of victory" (J.W. 3.123). ${ }^{62}$ The eagle, then, works precisely because it epitomizes the overwhelming nature of Roman power.

The collapsing of the four kingdoms motif into a one kingdom motif also occurs in another text that reacts to Roman rule- the book of Revelation. Dating to the early $90 \mathrm{CE}^{6}{ }^{63}$ its eschatological character and its references to Daniel mean that the book should be considered alongside Jewish apocalypses. ${ }^{64}$ In Revelation 12, a dragon that represents Satan stands on the shore (12:18) and then a beast with ten horns and seven heads comes forth (13:1). The dragon then gives the beast his power and his throne and authority (v. 2). In Revelation 17, the seven heads are interpreted as "seven mountains ... and they are also seven kings" (17:9-10). The seven mountains are those seven hills upon which Rome was famously built. ${ }^{65}$ The beast, therefore, represents imperial power and, more specifically, the Roman Empire.

Images from the four beasts of Daniel 7 figure prominently in the description of the beast. They all rise out of the sea (Rev 13:1). Revelation's beast has

61 Henry M. D. Parker, "Signa militaria," $O C D$ 1:1406. The eagle figures prominently in Roman mythology. For example, the eagle carried the thunderbolts of Jupiter, the patron deity of the Roman state. The eagle was also the bearer of omens (see, for example, Livy, The History of Rome, 1.34; and Pliny, Nat. 15.136-37).

62 A few decades later, Herod put a golden eagle above the gate of the renovated Temple (Ant. 17.151; J.W. 1.65o); the association between Rome and the eagle would have been obvious to those in Jerusalem. The eagle was also used to symbolize Rome in Jewish texts. See 1 QpHab 3:6-12 and the T. Mos. 10:8.

63 Irenaeus (Adv. Haer. 5.30.3) claimed that the book was in existence at the end of Domitian's reign (81-96 CE). For a discussion of both the external and internal evidence that supports this date, see Adela Yarbro Collins, Crisis and Catharsis: The Power of the Apocalypse (Philadelphia: Westminster, 1984), 54-83.

64 Pierre-Maurice Bogaert, "Les apocalypses contemporaines de Baruch, d'Esdras et de Jean," in L'Apocalypse johannique et l'Apocalyptique dans le Nouveau Testament, ed. J. Lambrecht (Leuven: Leuven University Press, 1980), 47-68.

65 Robert H. Mounce, The Book of Revelation (Grand Rapids: Eerdmans, 1977), 315. The connection with the Roman Empire is further supported by the details that one of the heads of the beast had a lethal but healed wound ( $\operatorname{Rev} 13: 3)$, an allusion to Nero, who legend holds survived a slit throat (Tacitus, Hist. I, 2 and II, 8). 
ten horns (Rev 13:1) like the fourth beast (Dan 7:7) and a total of seven heads (Rev 13:1) like all four beasts combined. The beast also has features of a leopard, a bear and a lion ( $\operatorname{Rev} 13: 2)$, paralleling the first three beasts in Daniel (Dan 7:4-6). The beast in Revelation speaks "haughty and blasphemous words" (Rev 13:5) just as the smallest horn of the fourth beast speaks "great things" against God (Dan 7:8, 20). ${ }^{66}$ Both Rev 13:7 and Dan 7:21 involve the beast making war against the holy ones. Finally, the beast's authority will last for fortytwo months ( $\operatorname{Rev} 13: 5)$, which is equivalent to three and a half years, the same amount of time that the holy ones in Daniel will be oppressed by the small horn (Dan 7:25). Like the eagle of 4 Ezra, characteristics of all the beasts of Daniel 7 have been subsumed into one beast. ${ }^{67}$

The collapsing of the multiple kingdoms is further symbolized by the whore, identified as "Babylon the great" ( $\operatorname{Rev} 17: 5)$, who rides on the beast. The physical conjoining of the Roman beast and the Babylonian whore signifies the enfolding of the two into one enduring imperial phenomenon. Babylon is Rome: "the representation of Rome as a foreign, peripheral creature ... is coupled seamlessly with the depiction of Rome as a wanton prostitute. Beast and Babylon, monsters both, must together submit to the divine will." 68 This is the same reason that in 4 Ezra the experiences of the author under the Roman Empire can be writ onto Ezra's own experience in the world of the Babylonian Empire. ${ }^{69}$ The fates of the beast of Revelation and the eagle of 4 Ezra are also the same. The horns of the beast "will devour [the whore's] flesh and burn her up with fire" (Rev 17:16). Since the whore is subsumed into the beast that is Rome, then Rome destroys itself. ${ }^{70}$ In a striking parallel, the eagle does the same - both devour themselves and then are burned up (Rev 17:6; 4 Ezra 11:35; 12:3). Revelation also shares with 4 Ezra the notion that the empire's vast might

66 There is also a possible parallel between the arrogant horn (Dan 7:20) and the beast in Revelation 17, which is "full of blasphemous names" (Rev 17:4). See Christopher A. Frilingos, Spectacles of Empire: Monsters, Martyrs, and the Book of Revelation (Philadelphia: University of Pennsylvania Press, 2004), 105.

67 For a list of similarities between Daniel 7 and Revelation 13, see Joseph Poon, The Identities of the Beast from the Sea and the Beast from the Land in Revelation 13 (Eugene, OR: Pickwick Publications, 2017), 20-21.

68 Frilingos, Spectacles, 105.

69 Yarbro Collins, Crisis and Catharsis, 57-58, argues that since the name Babylon on the whore's head is characterized as a "mystery" (Rev 17:5), then it is symbolic. She further suggests that this comparison came about because both empires destroyed the Jerusalem temple.

70 Greg Carey, "The Book of Revelation as Counter-Imperial Script," in In the Shadow of Empire: Reclaiming the Bible as a History of Faithful Resistance, ed. Richard Horsley (Louisville: Westminster John Knox Press, 2008), 167. 
only serves to ensure its total demise. Because of this, the four kingdoms motif is turned into a "one kingdom" motif.

Both texts also do away with the animal/human binary that was so explicit in the earlier, Greek period texts. The beast's ten horns fight against an opponent known as the Lamb, who is the "Lord of lords and King of kings" (Rev 17:14). The Lamb, of course, symbolizes the messiah. Similarly, in 4 Ezra, a lion foretells the death of the eagle (11:45-46). The lion is similarly identified as the messiah (4 Ezra 12:32). Unlike Daniel 7's son of man, the Testament of Naphtali's Joseph, or the Animal Apocalypse's shepherds and white men, the entities that signal the end of empire are not depicted as humans. ${ }^{71}$ Instead, the entities - the lion and the lamb-that stand in opposition to the empire are much more like the beastly empires. In fact, 4 Ezra's lion, much like the eagle, is a bit of a hybrid, having a man's voice (4 Ezra 11:37). Revelation's lamb, like the beast it goes to war with, has horns as well as multiple eyes (Rev 5:6).

\section{Conclusion}

By paying attention to the four kingdoms, we gain insight into how the paradigm was replicated to speak about empire in different texts in early Judaism. But, more significantly, we see how changes to the paradigm signal a shift in the way the imperial phenomenon was conceived. The understanding of the four empires of Daniel 7, the Testament of Naphtali and the Animal Apocalypse could not be sustained in the Roman period. Perhaps Rome was just too powerful or the destruction of the Second Temple and the loss of the Roman Revolt were too traumatic. Whatever the reasons, the authors of 4 Ezra and Revelation chose to portray empire as one, collective kingdom.

Additionally, by paying heed to the animal imagery incorporated into the four kingdoms motif, we see that, as Lévi-Strauss argued, animals are "good to think" with. All of these writers share a common set of imagery—empires were unnatural and fearsome beasts unlike any in the known world. This is precisely what a discourse does-it governs the production of truth in a society. ${ }^{72}$ This discourse was able to imagine new creatures. Some were based on the animals encountered by an agricultural society ${ }^{73}$ and others, like the eagle, mimicked

71 Although there is a parallel to the son of man in Rev 14:14 who flies with the clouds of heaven, the chapter is not contextually related to Revelation 13 (Poon, Identities, 56).

72 Frilingos, Spectacle, 9.

73 Stone, Reading, 117-139. 
the very images of imperialism itself. ${ }^{74}$ Empire as a phenomenon is nowhere conceptualized as one, particular animal. Even the Animal Apocalypse, which uses the most straightforward animal depictions, characterizes empires variously as lions, leopards, eagles, vultures, kites, and ravens. The depictions of empires are all quite literally hybrids — a mixture of beasts - as well as hybrid products that appear to "affirm the authority of the dominant culture ... but at another level by creating something inevitably different it unsettles and even mocks the supposed superiority of the colonial/imperial power."75 In other words, this animal discourse is playing into the empire's own view of itself-of course, it is powerful - but by distorting the beastly images, these texts undermine that power. Not coincidentally, this is how the four kingdoms motif itself works. In its original formation by the Persians, it was intended to convey that Persian universal rule was inevitable as it followed on the heels of Assyria and Media. The Romans ended up doing the same, adding themselves and the earlier Greeks to the series. ${ }^{76}$ As we have seen, however, when Jewish writers got ahold of this motif, they introduced a different ending — a divine kingdom that would usurp power - and, in this way, they changed a motif that served as imperial propaganda into anti-imperial rhetoric. ${ }^{77}$

The writers also created truth with this discourse by complicating the animal-human binary. In writing about resistance to hegemony in Daniel and the Animal Apocalypse, Anathea Portier-Young argues, "the very binary nature

74 Another example is to be found in the image of the lion, which was often identified with the king in the ancient Near East. The biblical text pointedly does not make this association, but displaces the imagery, portraying instead the lion as Yahweh. See Brent A. Strawn, What Is Stronger Than a Lion? Leonine Image and Metaphor in the Hebrew Bible and the Ancient Near East, ово 212 (Göttingen: Vandenhoeck \& Ruprecht; Fribourg: Academic Press, 2005), 152-186.

75 John M. G. Barclay, Against Apion: Translation and Commentary, vol. 10 of Flavius Josephus: Translation and Commentary, ed. Steve Mason (Leiden: Brill, 2007), lxix. R. S. Sugirtharajah puts it similarly, "The pure duality of hegemony, then, becomes a hybridity, since the subalterns' mimicry of hegemony can also be an appropriation, and hybridity can become a site of resistance against colonial authority as mimicry turns into mockery" (Exploring Postcolonial Biblical Criticism: History, Method, Practice [Malden, MA: Wiley-Blackwell, 2012], 15).

$7^{6}$ Brennan W. Breed, "Daniel's Four Kingdoms Schema: A History of Re-writing World History," Int 71 (2017): 178-89, esp. 181-82. This is apparent in the writings of Ctesias, a Greek physician working in the Persian court of Artaxerxes II in the beginning of the fourth century ВСЕ, who chronicled the order of the imperial powers as the Assyrians, Medes and Persians (Diodorus Siculus, Library of History 2.1-34). Similarly, Herodotus, in the fifth century BСE, includes a sequence of Assyrians, Medes and Persians (Herodotus, Histories 1.95, 130) to illustrate Cyrus's rise to power.

Breed, “Daniel's Four Kingdoms Schema," 182. 
of the hegemonic construction of reality ...(inside/outside, center/periphery, good/bad, civilized/barbaric, normal/aberrant) also creates the possibility for resistance to hegemony through critical inversion, wherein categories are retained but the hierarchy of values or assignment of value is turned upside down." 78 The example she gives is that of the Christian cross, which was transformed from a symbol of death to a symbol of redemption from death. This is what happens in Daniel, the Testament of Naphtali, and the Animal Apocalypse with the two, parallel binaries of animal/human and empire/subjugated. All three texts maintain a distinction between human and animal, but the binary of empire/subjugated is consistently inverted. To use Portier-Young's categories, the empire, despite what imperial ideology might want to convey, is an animal and as such it is barbaric, not civilized, it is aberrant, not normal, and it is bad, not good. Most significantly, since the human (i.e., the representation of a divine entity) brings about the end of the fearsome beast, imperial power is up-ended; the empire is weak whereas the subjugated Jewish people and their God are strong.

In the two Roman period texts, however, the binary between animal and human is removed. If the hegemonic construction of reality is based on binaries, then the authors of Revelation and 4 Ezra have dissolved the reality of an imperial world entirely. The empire and the Jewish people are both animals. They are on the same playing field, if you will. Moreover, by collapsing the four beasts into one, then that one beast is necessarily all-encompassing. Thus, the eagle and the beast with the whore are, in a sense, larger than life. However, the final lesson of the four kingdom qua one kingdom motif seems to be that the larger they are, the harder they fall.

\section{Bibliography}

Barclay, John M. G. Against Apion: Translation and Commentary. Vol. 10 of Flavius Josephus: Translation and Commentary. Edited by Steve Mason. Leiden: Brill, 2007 . Benjamin, Walter. Reflections, Essays, Aphorisms, Autobiographical Writings. Translated by Edmund Jephcott. New York: Harcourt Brace Jovariovich, 1986.

Berkowitz, Beth A. Animals and Animality in the Babylonian Talmud. Cambridge: Cambridge University Press, 2018.

Bizzarro, Laura. "The 'Meaning of History' in the Fifth Vision of 4 Ezra." Pages $3^{2-38}$ in Interpreting 4 Ezra and 2 Baruch: International Studies. Edited by Gabriele Boccaccini and Jason M. Zurawski. LSTS 87. New York: T\&T Clark, 2014. 
Bogaert, Pierre-Maurice. "Les Apocalypses contemporaines de Baruch, d'Esdras et de Jean." Pages 47-68 in L'Apocalypse johannique et l'Apocalyptique dans le Nouveau Testament. Edited by J. Lambrecht. Leuven: Leuven University Press, 1980.

Breed, Brennan W. "Daniel's Four Kingdoms Schema: A History of Re-writing World History." Int 71 (2017): 178-89.

Bryan, David. Cosmos, Chaos, and the Kosher Mentality. JSPSup 12. Sheffield: Sheffield Academic Press, 1995.

Carey, Greg. "The Book of Revelation as Counter-Imperial Script." Pages 157-76 in In the Shadow of Empire: Reclaiming the Bible as a History of Faithful Resistance. Edited by Richard Horsley. Louisville: Westminster John Knox Press, 2008.

Collins, Adela Yarbro. Crisis and Catharsis: The Power of the Apocalypse. Philadelphia: Westminster, 1984.

Collins, John J. The Apocalyptic Vision of the Book of Daniel. Missoula: Scholars Press for Harvard Semitic Museum, 1977.

Collins, John J. Daniel with an Introduction to Apocalyptic Literature. Grand Rapids: Eerdmans, 1984 .

Collins, John J. A Commentary on the Book of Daniel. Hermeneia. Minneapolis: Fortress Press, 1993.

Davila, James R. “The Animal Apocalypse and Daniel." Pages $35^{-38}$ in Enoch and Qumran Origins:New Light on a Forgotten Connection. Edited by Gabriele Boccaccini. Grand Rapids: Eerdmans, 2005.

Derrida, Jacques. The Animal That Therefore I Am. Translated by Marie-Louise Mallet. New York: Fordham University Press, 2008.

Doukhan, Jacques B. "Allusions à la creation dans le livre de Daniel." Pages 285-92 in The Book of Daniel in The Light of New Findings. Edited by A. S. van der Woude. Leuven: Leuven University Press, 1993.

Eggler, Jürg. Influences and Traditions Underlying the Vision of Daniel 7:1-14: The Research History from the End of the 19th Century to the Present. Fribourg: Fribourg University Press, 2000.

Flint, Peter W. "The Daniel Tradition at Qumran." Pages 329-67 in The Book of Daniel: Composition and Reception. Vol. 2 of Formation and Interpretation of Old Testament Literature. Edited by John J. Collins and Peter W. Flint with the assistance of Cameron Van Epps. VTSup 83. Leiden: Brill, 2001.

Flusser, David. "The Four Empires in the Fourth Sibyl and in the Book of Daniel." IOs 2 (1972): 148-75.

Foucault, Michel. Archaeology of Knowledge. Translated by A. M. Sheridan Smith. New York: Pantheon, 1972.

Frilingos, Christopher A. Spectacles of Empire: Monsters, Martyrs, and the Book of Revelation. Philadelphia: University of Pennsylvania Press, 2004.

Frisch, Alexandria. "Matthew 24:28: 'Wherever the Body is, There the Eagles Will Be Gathered Together' and the Death of the Roman Empire." Pages $5^{8-75}$ in The 
Gospels in First Century Judaea. Edited by R. Steven Notley and Jeffrey P. Garcia. JCPS 29. Leiden: Brill, 2015.

Frisch, Alexandria. The Danielic Discourse on Empire in Second Temple Literature. JSJS 176. Leiden: Brill, 2017.

García Martínez, Florentino and Eibert J. C. Tigchelaar, eds. The Dead Sea Scrolls Study Edition. Leiden: Brill, 1997.

Goff, Matthew. "Monstrous Appetites: Giants, Cannibalism, and Insatiable Eating in Enochic Literature." JAJ 1 (2010): 19-42.

Gruenthaner, Michael J. “The Four Empires of Daniel.” свQ 8.2 (1946): 201-12.

Henze, Matthias. Jewish Apocalypticism in Late First Century Israel: Reading Second Baruch in Context. TSAJ 142. Tübingen: Mohr Siebeck, 2011.

Humphreys, W. Lee. "A Life-Style for Diaspora: A Study of the Tales of Esther and Daniel." JBL 92 (1973): 211-23.

Kee, H. C. "Testaments of the Twelve Patriarchs." Pages $775^{-828}$ in vol. 1 of OTP. Edited by James H. Charlesworth. Garden City, NY: Doubleday, 1983.

Koch, Klaus. "Stages in the Canonization of the Book of Daniel." Pages 421-46 in The Book of Daniel: Composition and Reception. Vol. 2 of Formation and Interpretation of Old Testament Literature. Edited by John J. Collins and Peter W. Flint with the assistance of Cameron Van Epps. VTSup 83. Leiden: Brill, 2001.

Koosed, Jennifer L. "Humanity at Its Limits." Pages $3^{-12}$ in The Bible and Posthumanism. Edited by Jennifer L. Koosed. Atlanta: S BL Press, 2014.

Koosed, Jennifer L. and Robert Paul Seesengood. "Daniel's Animal Apocalypse." Pages 182-95 in Divinanimality: Animal Theory, Creaturely Theology. Edited by Stephen D. Moore. New York: Fordham University, 2014.

Kugler, Robert A. The Testaments of the Twelve Patriarchs. Sheffield: Sheffield Academic Press, 2001.

Lacocque, André. "Allusions to Creation in Daniel 7." Pages 114-31 in The Book of Daniel: Composition and Reception. Vol. 2 of Formation and Interpretation of Old Testament Literature. Edited by John J. Collins and Peter W. Flint with the assistance of Cameron Van Epps. VTSup 83. Leiden: Brill, 2001.

Miller, William Ian. The Anatomy of Disgust. Cambridge, MA: Harvard University Press, 1997.

Mills, Sara. Discourse. London: Routledge, 1997.

Mounce, Robert H. The Book of Revelation. Grand Rapids: Eerdmans, 1977.

Newsom, Carol with Brennan W. Breed. Daniel: A Commentary. otL. Louisville: Westminster John Knox Press, 2014.

Nickelsburg, George W. E. 1 Enoch 1: A Commentary on the Book of 1 Enoch, Chapters 1-36, 81-108. Hermeneia. Minneapolis: Fortress Press, 2001.

Otzen, Benedikt. Tobit and Judith. Sheffield: Sheffield Academic Press, 2002.

Parker, Henry M. D. "Signa militaria." ocD 1:1406. 
Poon, Joseph. The Identities of the Beast from the Sea and the Beast from the Land in Revelation 13. Eugene, OR: Pickwick Publications, 2017.

Portier-Young, Anathea E. Apocalypse Against Empire: Theologies of Resistance in Early Judaism. Grand Rapids: Eerdmans, 2011.

Raphael, Rebecca. "Monsters and the Crippled Cosmos: Construction of the Other in Fourth Ezra." Pages 279-301 in The "Other" in Second Temple Judaism: Essays in Honor ofJohn J. Collins. Edited by Daniel C. Harlow, Karina Martin Hogan, Matthew Goff, and Joel S. Kaminsky. Grand Rapids: Eerdmans, 2011.

Reynolds III, Bennie H. Between Symbolism and Realism: The Use of Symbolic and NonSymbolic Language in Ancient Jewish Apocalypses 333-63 B.C.E. JAJSup 8. Göttingen: Vandenhoeck \& Ruprecht, 2011.

Stone, Ken. Reading the Hebrew Bible with Animal Studies. Stanford: Stanford University Press, 2018.

Stone, Michael E. A Commentary on the Book of Fourth Ezra. Hermeneia. Minneapolis: Fortress Press, 1990.

Strawn, Brent A. What Is Stronger Than a Lion? Leonine Image and Metaphor in the Hebrew Bible and the Ancient Near East. ово 212. Göttingen: Vandenhoeck \& Ruprecht. Fribourg: Academic Press, 2005.

Strømmen, Hannah M. "Beastly Questions and Biblical Blame." Pages 13-28 in The Bible and Posthumanism. Edited by Jennifer L. Koosed. Atlanta: SBL Press, 2014.

Stuckenbruck, Loren T. "The Formation and Re-Formation of Daniel in the Dead Sea Scrolls." Pages 101-30 in The Dead Sea Scrolls and the Qumran Community. Vol. 2 of The Bible and the Dead Sea Scrolls. Edited by James H. Charlesworth. Waco: Baylor University Press, 2006.

Sugirtharajah, R. S. Exploring Postcolonial Biblical Criticism: History, Method, Practice. Malden, MA: Wiley-Blackwell, 2012.

Tcherikover, Victor. Hellenistic Civilization and the Jews. Philadelphia: Jewish Publication Society.

Tiller, Patrick. A Commentary on the Animal Apocalypse of 1 Enoch. EJL 4. Atlanta: Scholars Press, 1993.

Van Dijk, Teun A. "The Study of Discourse." Pages 1-34 in Discourse as Structure and Process. Edited by Teun A. van Dijk. London: Sage, 1997.

Wasserman, Mira Beth. Jews, Gentiles, and Other Animals: The Talmud After the Humanities. Philadelphia: University of Pennsylvania Press, 2017.

Weil, Kari. Thinking Animals: Why Animal Studies Now? New York: Columbia University Press, 2012.

Wolfe, Cary. "Human, All Too Human: 'Animal Studies' and the Humanities." PMLA 124 (2009): 564-74. 